\title{
Designing a Training Programme to Promote the Exercise of Self-Determination and Civic Engagement in Individuals Having an Intellectual Disability: Feedback on Collaborative Research
}

\author{
Barbara Fontana-Lana, Geneviève Petitpierre \\ Institut de Pédagogie curative, University of Fribourg (Switzerland), Rue Saint Pierre-Canisius 21, Fribourg, Switzerland \\ Email: barbara.lana@unifr.ch, genevieve.petitpierre@unifr.ch
}

How to cite this paper: Fontana-Lana, B., \& Petitpierre, G. (2017). Designing a Training Programme to Promote the Exercise of SelfDetermination and Civic Engagement in Individuals Having an Intellectual Disability: Feedback on Collaborative Research. Creative Education, 8, 975-992. https://doi.org/10.4236/ce.2017.86071

Received: March 14, 2017

Accepted: May 28, 2017

Published: May 31, 2017

Copyright $\odot 2017$ by authors and Scientific Research Publishing Inc. This work is licensed under the Creative Commons Attribution International License (CC BY 4.0).

http://creativecommons.org/licenses/by/4.0/

\begin{abstract}
Individual self-determination and civic engagement are key resources in the life of every individual. All the more so in the case of individuals with an intellectual disability (ID), who are frequently prevented, voluntarily or passively (for example through the failure to promote favourable conditions for learning), from implementing the resources that are required for acquiring and developing these skills. The importance of being able to apply these skills in everyday life is however acknowledged and encouraged by the UN Convention on the Rights of Persons with Disabilities (2006). This article presents and analyses the conditions for vertical and horizontal collaboration (Greenhalgh et al., 2004), which have contributed to the successful introduction of an educational approach to self-determination and active citizenship in a social care establishment for individuals having a mild to moderate ID. The research was conducted over two years (2014-2016) within the framework of a partnership between the establishment concerned and academic researchers. The principal stakeholders involved in the research, including 16 individuals with an ID, 13 educational care professionals, 4 members of the managerial staff and 4 research workers, worked together to promote the adoption of principles of self-determination and civic engagement within the establishment, and designed a training programme aimed at individuals with an ID and professional support staff. The effectiveness of the intervention mechanism applied by this team has been verified and validated using a pre- and post-test evaluation, the results of which have appeared in a separate publication. A qualitative analysis of the collaboration conditions indicates, and on first sight this may appear paradoxical, that individual self-determination and
\end{abstract}


its implementation are most successful when supported by a close-knit community, based on meaningful interdependence and mutually dependent relationships.

\section{Keywords}

Self-Determination, Civic Engagement, Collaborative Research, Intellectual Disability

\section{Scientific Knowledge and Its Implementation in a Social Care Environment, Importance of the Partnership}

Even when it is properly communicated, knowledge is not automatically translated into concrete action. Greenhalgh, Robert, Macfarlane, Bate, \& Kyriakidou (2004) refer to the necessity of moving on from the "let it happen" mindset to the "help it happen" or even the "make it happen" approach. Implementation is a task in itself. Encouragement has to be given to translate newly acquired knowledge into action (Beidas et al., 2013). Rogers (2003) suggests dividing the process into five stages-information, persuasion, decision, implementation, confirmation - to promote the application of knowledge or the implementation of a new programme. Starting with the information stage Lavis et al. (2003, quoted by Grimshaw, Eccles, Lavis, Hill, \& Squires, 2012) consider it essential to ask the following questions: Which aspects of the knowledge derived from the research are going to be transferred? Who is it going to be transferred to? How is this knowledge going to be transferred? What are the anticipated effects of the transfer of the knowledge derived from research? It is also vital to consider the "recipients" as a variable. This involves giving serious consideration to the way in which individuals and organisations "acquire, construct, synthesise, share and apply knowledge" (Russell, Greenhalgh, Boynton, \& Rigby, 2004: 1).The next, persuasion stage involves encouraging the potential adopters of the information to form a favourable or unfavourable opinion. The adoption of knowledge or new practices has more chance of success if the system commits itself and puts all its weight behind the implementation process (Beidas et al., 2013). The mere fact of providing correct information is actually not normally enough to bring about changes in practices or behaviour. People basically accept an innovation if they think it will be of use to them or their work (Tonneau \& da Rocha Barros, 2012; Tveden-Nyborg, Misfeldt, \& Boelt, 2013). The system needs to create opportunities to enable "potential adopters" to experience the innovation and to be supportive to them, while giving them enough freedom to "refine the innovation to improve its fitness for purpose" (Greenhalgh et al., 2004: 600). Belleau (2011) speaks of an "incubation period for research results before moving on to action" (paragraph 44). Time has to be allowed for new information to be digested and for a decision on whether to adopt or reject the innovation to be made. Moving on to a decision ( $3^{\text {rd }}$ stage) implies room for experimentation and reflexion. The 
motivational stake is crucial because people are in no way passive beneficiaries of the innovation.

"Rather (and to a greater or a lesser extent in different persons), they seek innovations, experiment with them, evaluate them, find (or fail to find) meaning in them, develop feelings (positive or negative) about them, challenge them, worry about them, complain about them, "work around" them, gain experience with them, modify them to fit particular tasks, and try to redesign them - often through dialogue with other users" (Greenhalgh et al., 2004: 598).

The $4^{\text {th }}$ and $5^{\text {th }}$ stages, referred to respectively as implementation (utilisation) and confirmation (maintenance and consolidation, achieved through the favourable impact) only come in at the end of the process.

The translation of knowledge and new practices into action is a complex process and therefore involves a long-term commitment that is difficult to quantify accurately (Russell et al., 2004). Abandoning the old ways of doing things in favour of innovative knowledge and practices is also more likely to be achieved through a collective process than an individual one. A distinction is made between the vertical and horizontal mechanisms (Greenhalgh et al., 2004). The planned and orchestrated communication of a new concept tends to be based on vertical relationships, whereas informal dissemination is achieved through horizontal relationships. In the latter case, the programming and implementation are more random, but horizontal relationships and peer pressure can be useful in the testing phase of innovations, to make sense of the innovation (ibid., p. 20).

\section{Adopting the Concepts of Self-Determination and, More Recently, of Civic Engagement}

In recent decades, training for self-determination has been labelled best practice in the field of special needs education (Shogren \& Broussard, 2011; Vatland, Strickland-Cohen, Loman, Doren, Horner, \& Walker, 2011). Self-determination means the action of an individual acting as a causalagent, that is to say a person who is the source of his own choices and actions (Wehmeyer, 2005). A person is said to be self-determined if that person makes decisions and choices for his own life, according to his preferences, wishes and values, in order to determine the level of control he wants to have over his own life, in order to maintain or enhance its quality (Wehmeyer, 1992, 2005).

There are currently several theoretical models (Abery \& Stancliffe, 1996; Mithaug, 1998; Wehmeyer, 1996; Wehmeyer, Abery, Mithaug, \& Stancliffe, 2003) as well as a number of research findings (Chambers, Wehmeyer, Saito, Lida, Lee, \& Singt, 2007; Jeong, Wehmeyer, Palmer, Soukup, Williams-Diehm, \& Shogren, 2012; Heller et al., 2011; Shogren et al., 2007; Wehmeyer et al. 2011; Zhang, 2005) that indicate how to support the deployment of self-determined actions by individuals with an ID. However on the ground, the application of the concept of self-determination may be welcomed and provide motivation but may also raise questions or even be off-putting on occasion. Various questions arise: are all the individuals capable of self-determination on every subject? How 
can we support them? Who can represent them? How can a balance be struck between self-determination and protection?, etc. Furthermore, in spite of the knowledge and material available, the right to self-determination is far from being well-known and its implementation on the ground is a long way off (Gardner \& Carran, 2005; Wehmeyer, 2015). And in any case, the Frenchspeaking regions only have access to a fraction of the material developed in English for the evaluation and promotion of self-determination skills. Everything has to be translated, adapted and most usually created from scratch.

Training for active citizenship is the other issue on which special needs education researchers have been focussing for a number of years. Active or participating citizenship can be defined as "the exercise of civil, social and political rights and the associated responsibilities, through the practice of participation, in a wide variety of places (association, group), at different levels (local, national, international)" (Tremblay \& Dufresne, 2009: 5). The aims associated with civic engagement are wide-ranging (Tremblay \& Dufresne, 2009) and the advantages for individuals with an ID are immediately obvious. These are threefold: integrating into the community, defining one's identity and contributing to the development of the community (Tremblay, 2011).

As scientific interest in active civic engagement on the part of individuals having an ID in the life of the community to which they belong is recent (Carney, 2013; Masse, Delessert, \& Dubath, 2014; Millar, 2007, 2008; Tremblay, 2009, 2012; Tremblay \& Lachapelle, 2006), there are currently no meta-researches that can be used as a basis in the way that there are for self-determination. The authors primarily offer general recommendations aimed at pointing out the practices that promote active citizenship in people with an ID, and still do not really offer training and/or incentive programmes as such (Tremblay, 2006; Masse, 2013). In the French-speaking region of Switzerland, where this particular study was conducted, the promotion of forms of active citizenship for individuals with an ID living in social-care establishments is relatively recent and it is mainly achieved by creating expression groups that generally operate as skills training laboratories (Masse, 2013). Individuals with a mild to moderate ID do participate, but people with a double diagnosis or a severe or profound cognitive impairment rarely do so. The discussions focus on the organisation of work and leisure in the establishment and rarely touch on activities outside the institution. Support for transferring skills acquired in this way to the world outside the establishment is rarely offered (Ossipow, 2012).

\section{Origin of the Research Project (and the Training for Self-Determination and Citizenship)}

The project began with an initial meeting between the university team and the management of a social care establishment offering centralised and decentralised residential and employment services to 180 adults affected by intellectual disability. This meeting took place on the initiative of the director and manager of the residential sector of this establishment who are both interested in imple- 
menting the principles of self-determination and civic engagement within the establishment. Following on from this meeting, a working group was set up, made up of 4 members of the managerial staff and 4 research workers who were asked to clarify the institutional needs and requirements and to address the conditions required for research on the implementation of self-determination and citizenship in an institutional environment. An initial proposal formally setting out the aspects discussed was drawn up by the academics and reviewed by the institutional partners, who supplemented and endorsed it. At the end of this initial stage, the working group made up of managerial staff and research workers formulated three objectives designed to provide a framework for the project:

1) The working group worked on the basis of the principle that self-determination and active citizenship should be considered as two sides of the same coin: one having individual validity and the other being more focused on the collective dimension (Masse et al. 2012). It appeared to go without saying that in order to get involved in active citizenship, a person with an ID must have a good awareness of "who they are" (know what they want, their needs, requirements, and be aware of their limits and strengths), know "what they are entitled to be" (know their rights, know that they can use them and believe that using them is a force for change that can influence the actual situation), know how to "create contexts out of the resources and constraints" (set oneself objectives, but also resolve the problems that may come between their wishes and the realisation of them), know how to take decisions and make choices. These skills that can be identified respectively as powers of self-fulfilment, empowerment, self-regulation and self-sufficiency, correspond to the essential characteristics of self-determination (Wehmeyer \& Bolding, 1999). At the same time, participatory citizenship calls for additional skills, more in keeping with the functioning and dynamics of the group, such as:

- knowing how to communicate (to speak up, express oneself clearly in front of several people, knowing how to listen, hold a conversation, argue a case, defend one's opinions, knowing how to take the opinions of others into account, communicate in a way that is non-confrontational);

- having the ability to identify viable and common lines of solution (find innovative solutions to discussion problems, diverging from the normal path, if necessary, to anticipate problems and solutions in a creative way);

- knowing how to vote (knowing how to reach a compromise, identify solutions as the will of the majority, while as the same time seeking solutions that are acceptable to the minority, conduct electoral activities without unsolicited external influences);

- knowing how to choose and accept a representative for the group to communicate with the other bodies of the community, etc.;

2) The working group also considered it necessary to support the introduction of the exercise of self-determination and engagement in citizenship by offering a training programme, both to individuals with an ID and support staff. The contents of the training programme were intended to support the 
self-determined skills and the engagement in citizenship of individuals with an ID and ensure that those around them offer and increase the opportunities for them to practise their skills in their daily lives. As no evidence-based practice (EBP) certified training programme fulfilling these objectives was available in French, it was decided to develop a new programme and to endorse it;

3) In order to meet the interests of the different stakeholders and partners, the working group set itself two objectives, namely a scientific objective (expansion of knowledge and development of tried and tested tools) and a social benefit objective (adoption and implementation of the principles of selfdetermination and active citizenship on the ground). Given that published works indicate that cooperation between researchers and non-researchers is one of the variables that make the research more directly "meaningful", a partnership was established between the University and those working in the field. The project is therefore clearly committed to a "participatory" research approach (also known as "collaborative" or "partnership-based", Bekelynck, 2011) that sees collaboration between research workers and the stakeholders on the ground as a key principle. The level of collaboration in this type of work is known to be liable to variation (Demange, Henry, \& Préau, 2012; Petitpierre, Scelles, Bungener, Detraux, \& Tremblay, 2016). In the research that we have conducted, the level of collaboration was exhaustive in the different stages described by Pentland et al. (2011): at the time of choosing the research topic in order to "situate and identify the knowledge requirements, identify the priorities and distinguish between them" (ib., p. 1417); at the time of establishing the research schedule; during the performance of the research; at the time of disseminating the results, which would also make it easier to translate knowledge into action.

\section{Identify the Knowledge Requirements and Establish the Priorities}

The collaboration that took place during the phase covering the launch of the research was by no means insignificant or of secondary importance when it came to contributing to the project's potential for success. The work on the joint development of objectives, the procedure for taking into account the needs on the ground and compliance with the requirements of the scientific process has already been mentioned above. The two parties involved, the social care establishment and the University, both had to bring their respective knowledge and expertise to the table, have talks, and listen to one another. This eventually enabled them to develop a balanced approach that would be to the advantage of the beneficiaries, because it is firmly bound by the constraints of the territory and respectful of those of the research. Funding was then sought to enable the project to go ahead. The task of obtaining financial support was mainly left to the staff of the social care establishment and was facilitated by the fact that the establishment in question belonged to a Foundation that is supportive of applied research. The project was submitted to the Foundation in connection with an invitation to submit project proposals that comes round every two years. After 
examining the objectives and conditions of the project, the Foundation concerned came out in favour and awarded the financial support that had been requested. The working group became a research team. Once funding had been obtained the project could go ahead. It attested to the scale of the commitment of the entire system to the attainment of the desired objectives and also represented a vertical endorsement of the approach defined by Greenhalgh et al. (2004) and Beidas et al. (2013). In the present case, the vertical endorsement was also achieved at various levels: international (UN Convention on the Rights of Persons with Disabilities, 2006), national (ratification of the Convention by Switzerland in 2014), institutional (support from the Council of the Eben-Hézer Foundation) and at the level of the establishment (expectations and commitment of the management and senior staff of the social care establishment). Once these stages had been accomplished, the process of joint development of the training programme for self-determination and active citizenship could begin.

\section{Process of Joint Development of a Training Course for Self-Determination and Active Citizenship}

The theoretical lines for the structure of the training programme were largely developed by the research team and subsequently endorsed by the management of the institution. The content and the method of transmission, i.e. how it is translated into practical activities, the teaching and the didactic process used to promote learning, the material, such as for example, the use of material containing images, video, educational scenarios, role-play, and finally, subjects for discussion, were, however, developed in consultation with the participants, including those with an ID. The training programme, aside from the invitation to participate, allowed for three preliminary sessions (Phase 1: preparation) in which the participants were invited to express their wishes, requirements, difficulties, obstacles as regards translating the principles of self-determination and civic engagement into practice: the educational care professionals $(\mathrm{N}=13)$ and the individuals with an ID $(\mathrm{N}=16)$ were consulted in groups of 8 , then all together in a full session. The aim was to record the concerns expressed by the majority of participants in order to clarify the content, i.e. the themes on the basis of which self-determination and citizenship skills can be practised. Staff from the institution also took part in the full session. The sessions identified four themes that were of interest to the majority of individuals with an ID and the majority of the educational care professionals, namely "housing and living conditions", "leisure and lifelong learning", "emotional development (friendship and life as a couple)" and finally "freedom to make decisions" in the broad sense. These initial sessions, organised prior to the training, adopted a procedure intended to enable various recipients of training to express themselves, each according to their own specific perspective and to assist in identifying the topics for discussion. The motivational stake already mentioned above (Greenhalgh et al., 2004) was fully taken into account. The full session aimed to set out the positions in a way that was clear. The individuals with an ID were able to see that 
their words were taken seriously by all partners: the managerial staff of the institution, research team and individuals with an ID were all accorded equal importance (the right to be heard, the opportunity to listen, the right to vote). The selected method also delivered the following message to the participants: recognition of an equivalent level of expertise based on the experience of each person (individuals with an ID and/or educational care professionals), the access and the right of each person to take part in the dialogue in order to identify comprehensive and intelligent solutions.

The participation dynamic between the research team and the training participants was also taken into account throughout the study: at the end of each day of training, the research team went back over the progress achieved, the obstacles encountered, the relevance of the teaching methods selected and the most notable anecdotes to enable them to adapt the schedule for the next session. A number of examples and educational scenarios could be derived from the experiences, the questions or misgivings that the participants brought to the sessions. The training participants were given a record of the course content, the teaching methods used, the changes discussed and the thoughts shared, after each session. The reports intended for the individuals with an ID were drafted in language that was easy to read and understand and they were illustrated with pictograms. Basically, a considerable amount of time was devoted to dialogue with the recipients of the training, discussions and the development of joint decisions during the sessions or, within the research team, between the sessions, on the recommendation of O'Brien et al. (2014).

\section{Adapting the Programme to the Special Educational Needs of Learners with an ID}

The groups of individuals with an ID made a direct and indirect contribution to the development of the content covered, the material used, as well as the proposed didactic conditions throughout the training. Their reactions, their comments, their difficulties and their opportunities, constantly encouraged the research team to evaluate, question and fine-tune the training programme that had been designed originally. So the tools or the aids originally considered on the basis of certain factors had to be adjusted along the way to the needs and actual situations encountered. For example, certain pictograms were abandoned at the request of the groups in favour of others that were felt to be more representative and more accessible. Or a procedure for voting by a show of hands was changed to a secret ballot system to avoid outside influence ${ }^{1}$. As mentioned above, people with an ID (and the educational care professionals) were regularly given an opportunity to speak to ensure that the training format was appropriate for them. The improvements that were gradually made to the programme confirmed the learners in their role as stakeholders, demonstrating that their thoughts had been listened to and had had a direct impact on both the content and the teaching

\footnotetext{
${ }^{1}$ Information concerning the mechanism and tools developed can be found under the heading
} "Publications" on http://fns.unifr.ch/autodetermination/fr/publications. 
methods. We would like to emphasise the importance of this type of process which inspires and motivates the participants, and suggests that the various phases of the implementation need to be designed in a spiral motion, going back and forth between information, persuasion and decision-making etc., rather than a linear process with successive, clearly limited stages.

\section{The Contribution of the Partners on the Ground within the Research Team}

As well as contributing to the deliberations of the research team, the supervising care professionals and the management staff of the institution assisted in the accomplishment of the research and ensured it could proceed smoothly by acting as intermediaries and points of contact for the learners. Their contribution proved to be invaluable on a number of occasions, for example by helping to decode the verbal or non-verbal communication patterns of some residents during the training sessions conducted by the academics, getting involved in the event of the absence of learners (care professionals or people with ID) at the training sessions convened, establishing a link between the families and/or legal guardians or to promote the understanding of factors of a contextual and organisational nature, parallel to the training but having an effect on it, and otherwise not accessible to the academics. We can illustrate this contribution by three concrete examples:

1) During a training session, one participant was being particularly aggressive and irritable towards other participants in the group. It was only when the care supervisor and the care team were consulted on the subject that we were able to understand that an argument had taken place a few days previously in the living group, between the participant in question and other people participating in the training, over an alleged theft of money. The situation was openly discussed with the participant (care professionals and trainers) so that an atmosphere conducive to the smooth operation of the training could be restored.

2) During one session a participant fell asleep with her head between her arms on the table. Once again it was only by consulting the other care partners that we were able to adapt our action in a better way, by associating her behaviour with her specific physical and psychological health, rather than attributing it to motivation or problems of understanding during the session itself.

3) At every session one participant expressed a wish to have a private shower. By consulting the other care partners we were able to understand that this request had only been expressed during the training and that, although persistent and repetitive, had not however gone beyond the closed doors of the sessions, which at this stage made it extremely unlikely that the request would be granted. This information enabled us to focus during the sessions on the aspects of self-determination that would be particularly useful for this person's objectives (and for the other participants as well), such as the need to express her requirements clearly, to put them to people who are better 
placed to address them, at different levels and in various contexts, and to persevere in her request to obtain a response.

\section{The Contribution of the Academics within the Research Team}

The work of the academics focused mainly on the description and documentation of the theoretical principles, as well as going back over the methodological principles governing a scientific study aiming to evaluate the effectiveness of an intervention. A brief inventory was made of options available in terms of experimental plans, detailing their respective strengths, weakness and constraints and a quasi-experimental plan involving pre- and post-test stages and a control group was adopted. The academics were also specifically involved in establishing the working assumptions in the choice of the tools used in the initial evaluation and the final evaluation, as well as in the verification of the composition and the balance of groups (experimental and control).

The operational objective of our research was firstly, to develop training resources designed to promote the exercise of self-determination and civic engagement in individuals having an ID in an institutional environment and to test the effectiveness of these resources; secondly, to pinpoint the contextual and didactic conditions that favour this practice in the place where people live. The following hypotheses were established: 1) the proposed training and the tools developed promote the enhancement of self-determination skills in individuals with a mild or moderate ID living in an institutional environment; 2) the presence of educational care professionals, their involvement and their collaboration in the programme for training individuals with ID helps the latter to acquire the essential principles of self-determination. During the intervention stage, the residents and the educational care professionals followed a training programme (Fontana Lana, Angéloz Brügger \& Petragallo Hauenstein, 2017) in which the first module provides training in self-determination and the second focuses on civic engagement. The training was conducted in 3 groups, 1 group made up solely of professionals (Group 1), another group made up solely of residents (Group 2) and a mixed group of residents and professionals (Group 3).

The effectiveness of the training (13 sessions in all) was tested by measuring the skills of the individuals with an ID belonging to groups 2 and 3 , in the preand post-test stages. Two indicators were used. The first was the LARIDI scale (Lachapelle, Boisvert, \& Leckerc, 2000; Lachapelle, Haelewyck, \& Leclerc, 2002) which is a scale designed for the measurement of the level of self-determination of adolescents and adults having an ID. The second was the Choice Questionnaire (Stancliffe \& Parmenter, 1999) which aims to identify the perception of opportunities for choice in adults with an ID. The report presenting the full results obtained and details of the research has already been published (FontanaLana, Angéloz Brügger, Gobet, \& Hauenstein, 2016). We shall therefore confine ourselves to the principal results, which confirm that after the training:

- The individuals having an ID showed a higher level of self-determination, 
particularly as far as self-regulation was concerned $(\mathrm{Z}=67.5, \mathrm{p}<0.05)$;

- The increased noted was significantly higher in the group of participants having an ID who undertook the training in the presence of educational care professionals incorporated into the group $(U=21.00, p<0.05)$ compared with the other group made up solely of individuals with an ID;

- The individuals with an ID also increased their perception of the opportunities for choice in their domestic activities and their daily lives $(Z=55.5, p<$ $0.5)$.

As regards the individuals having an ID, we should mention certain effects that are more qualitative in nature, but no less important, that were identified in the personal trajectory of various individuals who took part in the research. For example the person who wanted a private shower managed to make the necessary approaches to obtain what she wanted.

\section{Follow-Up and Incidental Benefits of the Training}

The task of following up the training and ensuring that the benefits derived from it were achieved was passed to the establishment, with the academic participants progressively standing back to make way for the creation of an internal focus group. The objective of this group, made up of four individuals with an ID (all having taken part in the research), one educational care professional, one parent and a moderator, was to come up with a proposal for entrusting future implementation of the project to the institution in a way that would guarantee and reinforce application of the principles of self-determination and active citizenship within the establishment. This type of transition is in keeping with Ninacs' concept of organisational empowerment $(2003,2008)$. Following on from the working group referred to, a permanent internal committee was set up within the establishment. It is made up off our persons with ID, a support person, a supervisor from outside the establishment and a moderator. It is governed by statutes and its members are elected. It meets regularly and its objective is to continue the implementation and consideration of self-determination and civic engagement in the establishment, with the support of all the relevant partners. At the same time, the establishment has also added the training course to its permanent internal training programme. At the time of writing this article, the training course is being offered for the third consecutive time. The establishment has also engaged a member from the academic circle on a part time basis to continue to inspire the focus group and drive the implementation forward, and to exploit the synergies between the academics and the establishment to the full.

The academic dividends from the process have been considerable: it has inspired several publications (scientific articles, a training manual, a cartoon strip aimed at the public), attendance at national or international scientific congresses or discussion meetings, presentations to other establishments or associations. In the course of these activities, new collaborations have emerged, contributing to the thought processes and reciprocal sharing of expertise, both between researchers and between researchers and practitioners. The results are circulating, 
so to speak, and are disseminated both under the impact of vertical factors (organised and structured events) and more random factors (horizontal), but with the same driving force. For example, a presentation to an association of self-advocates ("The person first") in Belgium enabled information on this collaborative approach and its tools to be passed to Canadian researchers who already had links with the association in the French-speaking area of Belgium.

The benefits mentioned clearly show the advantage of building bridges between the research results and the action. The approach adopted by this research basically invites reflection and is intended to bring researchers, institutional stakeholders and those close to them closer together, confirming that it is possible to structure rigorous scientific projects geared to future application, reinforcing the need for and the importance of a constructive and pragmatic dialogue between all the partners.

\section{Discussion and Conclusion}

The concepts of self-determination and civic engagement are rooted in the societal changes that are typical of the modern era. Whatever the field, relations between the community and its members are currently being redefined in the light of the challenges of the moment, such as, for example, the flow of migrants, multiculturalism, defence of minorities and their rights and economic uncertainties, which test and question the concepts of democracy and solidarity. Socio-educational support is no exception. The interaction within the educational relationship is changing, moving in the direction of a fairer distribution of power between the partners (Tremblay et al., 2011). The demand for rights of individuals with an ID, in all aspects of their life, the national and international legal initiatives to formalise these rights, of which the most important is of course the UN Convention on the Rights of Disabled Persons of 2006, are good illustrations of the direction taken and desired by socio-educational support (and upheld by all of society) for the beneficiaries as regards self-determination and citizenship.

So, the stakes go beyond and open up the frontiers of socio-educational support itself. The challenge is to build an inclusive and competent society for every citizen, whether they are vulnerable or not. In this sense "a competent community is a community whether the different systems are able to respond to the needs of individuals and the individuals are able to use the systems in an effective way" (Ninacs, 2003: 9). This community presupposes the existence of a democratic political will, defined as follows: "a democratic state is a society of shared rights, duties and responsibilities" (Tremblay, 2006: 8). The importance of democratic development must be understood in the sense of a taking action against any form of discrimination (Tremblay, 2006), of a responsibility for the unity of society (Vitiello, 2008), and for building together (Schnapper, 2001). The moment has come to move on from talking about principles to their implementation.

This collaborative research approach (Tremblay \& Hudon, 2014) has demon- 
strated that every person, with their own expertise, is indispensable to the others, when considering together how to promote the implementation of self-determined actions and civic engagement. The collaborative methods used in this project emphasise the advantage for all persons involved in an educational process, to see themselves as one big team for the resolution of problems and creation of innovative solutions, rather than as individual players with different interests who must position themselves in relation to one another to defend their respective positions. This idea is in line with the notion of "community of practice" of Wenger (1998), also endorsed by O'Brien and colleagues (2014).This research, summarised in appendixl, on the basis of the stages referred to by Demange et al. (2012), the stages followed by the members of the collaborative team, has made it possible to prove, something which on first sight, may appear to be paradoxical: individual self-determination is most successful when it is derived from the community. A person is born, then develops, acquires his or her own unique and distinctive personality, if he or she can evolve and has the support of a close-knit community, based on meaningful independence and mutually dependent relationships.

There were limitations, such as the place accorded to the families of the individuals concerned. It is definitely one our great regrets that we did not involve the parents or relatives and the legal representatives from the outset. This choice was made solely on the basis of the need to balance the resources available with the objectives of the project. The relatives and legal representative were notified in writing at the commencement of the research and subsequently additional details were provided on request. Telephone contacts were made and letters were written during the intervention phase. Nevertheless, we are convinced that establishing a collaboration and jointly deciding on the approach for implementation of self-determination and civic engagements with the relatives and legal representatives would have been even more beneficial in terms of the desired objectives. An evening reception organised by the establishment for relatives and parents addressed the relatives' need to be heard and recognised, as well as their wish to be more involved in the processes and changes in progress. Unfortunately this meeting took place once the research had been completed and in the present case the collaboration with relatives was therefore confined to the transmission of information with discussion, which is not enough to be able to call it working in partnership. In this respect Arnstein's Ladder is extremely useful in reminding us that "participating" and "jointly developing"(Arnstein, 1969), mean having a real impact on decision-making, at all levels and at all the stages of the process, and not only being informed or consulted to express their own opinion.

Of course the demands of families also raise ethical questions: the individuals with ID who took part in the project are all adults. Some of them did not want their parents to be involved in the training and were keen to be able to express themselves, for example in the full session, without their parents hearing what they had to say. How can these contradictory demands be respected? We believe 
that, just as in any parent-child relationship, whether they have an ID not, any individual, even if they are an adult, benefits from engaging in dialogue with those around them and this should be safeguarded as far as possible. In the situation of a person with an ID, if the legal representative objects to their decisions or demands, that person currently has little chance of getting their way- in Switzerland at least. A good example of this is a participant forced by parents to stop the training when they wanted to take part. The implementation of self-determination means that it is also necessary to prepare the person's circle, including the family circle. This is indisputably one of the steps that need to be taken as a follow up to this work and more generally in the research on the subject of self-determination.

\section{References}

Abery, B. H., \& Stancliffe, R. J. (1996). The Ecology of Self-Determination. In D. J. Sands, \& M. L. Wehmeyer (Eds.), Self-Determination across the Life Span: Independence and Choice for People with Disabilities (pp. 111-145). Baltimore: Paul H. Brookes.

Arnstein, S. R. (1969). A Ladder of Citizen Participation. Journal of the American Institute of Planners, 35, 216-224.

http://www.historyofsocialwork.org/1969_ENG_Ladderofparticipation/1969,\%20Arnst ein,\%20ladder\%20of\%20participation,\%20original\%20text\%20OCR\%20C.pdf https://doi.org/10.1080/01944366908977225

Beidas, R. S., Aarons, G., Barg, F., Evans, A., Hadley, T., Hoagwood, Mandell, D. S. et al. (2013). Policy to Implementation: Evidence-Based Practice in Community Mental Health-Study Protocol. Implementation Science, 8-38.

https://doi.org/10.1186/1748-5908-8-38

Bekelynck, A. (2011). Review of International Literature on Communitary Research. Synthesis (p. 14). Working Paper, Paris: CEPED. http://www.ceped.org/IMG/pdf/ceped_wp14.pdf

Belleau, H. (2011). Frommobilization of Knowledge to Partnership of Research. http://sociologies.revues.org/3730

Carney, T. (2013). Participation and Service Access Rights for People with Intellectual Disability: A Role for Law? Journal of Intellectual \& Developmental Disability, 38, 59-69.

Chambers, C. R., Whemeyer, M. L., Saito, Y., Lida, K. M., Lee, Y., \& Singh, V. (2007). Self-Determination: What Do We Know? Where Do We Go? Exceptionality, 15, 3-15.

Demange, E., Henry, E., \& Préau, M. (2012). From Collaborative Research to Communitary Research. A Methodological Guide. Paris: ANRS/Coalition Plus. Coll. Sciences sociales et sida.

Gardner, J. F., \& Carran, D. T. (2005). Attainment of Personal Outcomes by People with Developmental Disabilities. Mental Retardation: A Journal of Practices, Policy and Perspectives, 43, 157-174. https://doi.org/10.1352/0047-6765(2005)43[157:AOPOBP]2.0.CO;2

Greenhalgh, T., Robert, G., Macfarlane, F., Bate, P., \& Kyriakidou, O. (2004). Diffusion of Innovations in Service Organizations: Systematic Review and Recommendations. Milbank Quarterly, 82, 581-629. https://doi.org/10.1111/j.0887-378X.2004.00325.x

Grimshaw, J.-M., Eccles, M. P., Lavis, J. N., Hill, S. J., \& Squires, J. E. (2012). Knowledge Translation of Research Findings. Implementation Science, 7, 50. 
https://doi.org/10.1186/1748-5908-7-50

Heller, T., Schindler, A., Palmer, S. B., Wehmeyer, M. L., Parent, W., Jenson, R., O’Hara, D. M. et al. (2011). Self-Determination across the Life Span: Issues and Gaps. Exceptionality, 19, 31-45. https://doi.org/10.1080/09362835.2011.537228

Jeong, S. H., Wehmeyer, M. L., Palmer, S. B., Soukup, J. ., Williams-Diehm, K., \& Shogren, K. A. (2012). Examining Individual and Environmental Factors on Levels of Self-Determination of Students with Disabilities: The Relationship between Self-Determination and Disability Categories, Gender, and Educational Settings. The Journal of Special Education: Theory and Practice, 6, 1-22.

Lachapelle, Y., Boisvert, D., \& Leclerc, D. (2000). Translation and Cross-Cultural Validation of ARC's Scale of Self-Determination. In Presentedat Recherche Défi, Revue francophone de la déficience intellectuelle (pp. 70-74).

http://www.rfdi.org/wp-content/uploads/2013/06/LACHAPELLE_v11sp-70-74.pdf

Lachapelle, Y., Haelewyck, M.-C., \& Leclerc, D. (2002). Evaluation of Quebec's Version of the Self-Determination Scale with Québéquois and Belgian Adults Presenting an Intellectual Disability. In Revue francophone de la déficience intellectuelle (pp. 47-50).

http://w3.uqo.ca/transition/tva/wp-content/uploads/1A3_\%C3\%89valuation_version_q u\%C3\%A9b\%C3\%A9coise_\%C3\%A9chelle_d\%C2\%B4autod\%C3\%A9termination_adu ltes_qu\%C3\%A9b\%C3\%A9cois_belges_pr\%C3\%A9sentant_DI.pdf

Masse, M. (2013). Self-Determination: Training the Supporters. Revue Reiso. http://www.reiso.org/spip.php?article3233

Masse, M., Delessert, Y., \& Dubath, M. (2014). Expression Spaces within Establishments for Adults with an Intellectual Disability: Types and Participation. Revue suisse de pédagogie spécialisée, No. 2, 51-57.

Masse, M., Ossipow, L., Delessert, Y., Tremblay, M., Lucas, B., Csupor, I., \& Junod, R. (2012). Educational Forms and Citizenship Processes. In International Colloquium: Educational Forms and Citizenship Processes. http://python.espe-bretagne.fr/recace/fepe_2012/Symposiums/Masse.pdf

Millar, D. S. (2007). ERIC_- “I Never Put It Together": The Disconnect between Self-Determination and Guardianship-Implications for Practice. Education and Training in Developmental Disabilities, 42, 119-129.

Millar, D. S. (2008). Self-Determination in Relation to Having or Not Having a Legal Guardian: Case Studies of Two School-Aged Young Adults with Developmental Disabilities. Education and Training in Developmental Disabilities, 43, 279-293.

Mithaug, D. E. (1998). Invited Commentary: Your Right, My Obligation? Journal of the Association for Persons with Severe Handicaps, 23, 41-43.

Ninacs, W. A. (2003). Empowerment: Conceptual Framework and Tools to Evaluate Social and Communitarian Intervention. La Clé. http://envision.ca/pdf/w2w/Papers/NinacsPaper.pdf

Ninacs, W. A. (2008). Empowerment and Intervention: Developing the Ability to Act and Solidarity. Québec: Les Presses de l'Université Laval.

O’Brien, P., McConkey, R., \& Garcia-Iriarte, G. (2014). Co-Researching with People Who Have Intellectual Disabilities: Insights from a National Survey. Journal of Applied Research in Intellectual Disabilities, 27, 65-67.

https://doi.org/10.1111/jar.12074

Ossipow, L. (2012). Citizenship, Participation and Emancipation in a Teenager Shelter. In International Colloquium: Educational Forms and Citizenship Processes (pp. 6-14).

Pentland, D., Forsyth, K., Maciver, D., Walsh, M., Murray, Sikora, S. et al. (2011). Key Characteristics of Knowledge Transfer and Exchange in Healthcare: Integrative Litera- 
ture Review. Journal of Advanced Nursing, 67, 1408-1425.

https://doi.org/10.1111/j.1365-2648.2011.05631.x

Petitpierre, G., Scelles, R., Bungener, M., Detraux, J.-J., \& Tremblay, M. (2016). Leading Research Inpartnership with Social, Economic and Politicsplayers. Contraste, 443, 245265. https://doi.org/10.3917/cont.043.0245

Rogers, E. M. (2003). Diffusion of Innovations (5th ed.). New York, NY: Free Press, Simon \& Schuster.

Russell, J., Greenhalgh, T., Boynton, O., \& Rigby, M. (2004). Soft Networks for Bridging the Gap between Research and Practice: Illuminative Evaluation of Chain. British Medical Journal, 328, 1-6. https://doi.org/10.1136/bmj.328.7449.1174

Schnapper, D. (2001). History, Citizenship and Democracy. Vingtième Siècle. Revue d'histoire, 71, 97-103. https://doi.org/10.3917/ving.071.0097

Shogren, K. A., \& Broussard, R. (2011). Exploring the Perceptions of Self-Determination of Individuals with Intellectual Disability. Intellectual and Developmental Disabilities, 49, 86-102. https://doi.org/10.1352/1934-9556-49.2.86

Shogren, K. A., Wehmeyer, M. L., Palmer, S. B., Soukup, J., Little, T. D., Garner, N., \& Lawrence, M. (2007). Examining Individual and Ecological Predictors of the Self-Determination of Students with Disabilities. Exceptional Children, 73, 488-509. https://doi.org/10.1177/001440290707300406

Stancliffe, R., \&Parmenter, T. R. (1999). The Choice Questionnaire: A Scale to Assess Choices Exercised by Adults with Intellectual Disability. Journal of Intellectual and Developmental Disability, 24, 107-32. https://doi.org/10.1080/13668259900033911

Tremblay, M. (2006). For the Exercise of Civil, Economic, Social, Cultural, and Political Rights (pp. 1-17). International Educational Program for the Democraticcitizenship of People Presenting Intellectual Disability or Mental Handicap, AIRHM, OQD.

Tremblay, M. (2009). Citizen Participation, Civiccommitment and Political Efficiency for Members of User Committees or Societies. Recherche en Communication, 32, 119-133.

Tremblay, M. (2011). Emancipation Movement of People Having Functional Limitations: Recognition of Political Participation's Rights. International Network on the Process of Production of the Handicap. http://www.ripph.qc.ca/fr/revue/journal-19-02-2011-02

Tremblay, M. (2012). Education of Citizenship and Development of Civic Skills for People Having Functional Limitations: Recognizing the Rights to Political Participation. In the International Colloquium: Educational Forms and Process of Citizenship.

Tremblay, M., Cudini, A., \& Blais, M. (2011). Citizen Participation and Intellectual Disability: Speaking in One's Own Name. Revue du Cremis, 4, 10-14.

Tremblay, M., \& Dufresne, J.-S. (2009). For Fun ... The Involvement and the Civic Commitment of the Laurentide Youth. Report of the Action Research on the Involvement and the Civic Commitment of the Laurentian Youth, Submitted at the Entente sur l'Education à la Citoyenneté.

Tremblay, M., \& Hudon, I. (2014). Participative and Emancipatory Research in Intellectual Disability: Moving towards Citizenship Ethics. In G. Petitpierre, \& B.-M., Martini-Willemin (Eds.), Research Methods in the Field of Intellectual Disabiliy (pp.149-159). Bern: Peter-Lang.

Tremblay, M., \& Lachapelle, Y. (2006). Users' Social and Democratic Participation in the Planning and Organization of Services. In D. Gascon, D. Boisvert, M.-C. Haelewyck, J.-R. Poulin, \& J.-J. Detraux (Eds.), Intellectual Disability: Perspectives on Knowledge 
and Action (p. 1). Cap-Rouge: AIRHM Presses Inter Universitaires.

Tonneau, J.-P., \& da Rocha Barros, E. (2012). Between Utilitarianism and Pessimism: Towards a Useful, Usable and Used Research. Vertigo. http://vertigo.revues.org/12164

Tveden-Nyborg, S., Misfeldt, M., \& Boelt, B. (2013). Diffusing Scientific Knowledge to Innovative Experts. Journal of Science Communication, 12, 1-11.

UN (2006). Convention on the Rights of Persons with Disabilities and Optional Protocol. www.un.org/disabilities/documents/convention/convoptprot-e.pdf

Vatland, C., Strickland-Cohen, K., Loman, S., Doren, B., Horner, R., \& Walker, H. (2011). Promoting Self-Determination for Adults: A Practice Guide (pp. 1-52). A National Gateway to Self-Determination. www.aucd.org/ngsd

Vitiello, A. (2008). Citizenship Education. Raisons Politiques, 29, 169-187. https://doi.org/10.3917/rai.029.0169

Wehmeyer, M. L. (1992). Self-Determination and the Education of Students with Mental Retardation. Education and Training in Mental Retardation, 27, 302-314.

Wehmeyer, M. L. (1996). Student Self-Report Measure of Self-Determination for Students with Cognitive Disabilities. Education and Training in Mental Retardation and Developmental Disabilities, 31, 282-293.

Wehmeyer, M. L. (2005). Self-Determination and Individuals with Severe Disabilities: Re-Examining Meanings and Misinterpretations. Research and Practice for Persons with Severe Disabilities, 30, 113-120. https://doi.org/10.2511/rpsd.30.3.113

Wehmeyer, M. L. (2015). Framing the Future: Self-Determination. Remedial and Special Education, 36, 20-23. https://doi.org/10.1177/0741932514551281

Wehmeyer, M. L., Abery, B. H., Mithaug, D. E., \& Stancliffe, R. J. (2003). Theory in Self-Determination: Foundations for Educational Practice. Springfield, IL: Charles C. Thomas Publisher, LTD.

Wehmeyer, M. L., Abery, B. H., Zhang, D., Ward, K., Willis, D., Hossain, W. A., Walker, H. M. et al. (2011). Personal Self-Determination and Moderating Variables That Impact Efforts to Promote Self-Determination. Exceptionality, 19, 19-30.

https://doi.org/10.1080/09362835.2011.537225

Wehmeyer, M. L., \& Bolding, N. (1999). Self-Determination across Living and Working Environments: A Matched-Samples Study of Adults with Mental Retardation. Mental Retardation, 37, 353-363. https://doi.org/10.1352/0047-6765(1999)037<0353:SALAWE>2.0.CO;2

Wenger, E. (1998). Communities of Practice: Learning, Meaning and Identity. Cambridge: Cambridge University Press. https://doi.org/10.1017/CBO9780511803932

Zhang, D. (2005). Parent Practices in Facilitating Self-Determination Skills: The Influence of Culture Socioeconomic Status, and Children's Special Education Status. Research and Practice for PersonswithSevereDisabilities, 30, 154-162.

https://doi.org/10.2511/rpsd.30.3.154 


\section{Appendix 1. Stages of the Project}

\begin{tabular}{|c|c|c|c|}
\hline Persons involved & \multicolumn{2}{|c|}{ Stages of the research } & Nature of the collaboration \\
\hline $\begin{array}{l}\text { Staff from the Cité (name of the establishment) - } \\
\text { Academic staff Unifr }\end{array}$ & $\begin{array}{l}\text { Phase } 0 \text { : } \\
\text { Preparation of the } \\
\text { research project }\end{array}$ & $\begin{array}{l}\text { Meeting potential } \\
\text { partners }\end{array}$ & $\begin{array}{l}\text { Formulation of expectations (specifying } \\
\text { needs, resources, possible working } \\
\text { methods) } \\
\text { - Framework of potential collaboration }\end{array}$ \\
\hline Academic staff - Staff from the Cité & & $\begin{array}{l}\text { Drafting project } \\
\text { proposal }\end{array}$ & $\begin{array}{l}\text { - Endorsement of objectives and the } \\
\text { methods of achieving them }\end{array}$ \\
\hline Eben-Hézer Foundation & & Acceptance of project & $\begin{array}{l}\text { - Commitment of the entire system: } \\
\text { providing a basis for the realisation of the } \\
\text { project and financial support }\end{array}$ \\
\hline Academic staff Unifr - Staff from the Cité & Phase 1: & Call for participants & - Motivation of participants \\
\hline $\begin{array}{l}\text { Academic staff Unifr - Participants (individuals } \\
\text { with and educational care professionals), } \\
\text { Member of staff from the Cité }\end{array}$ & Preparatory sessions & Preliminary sessions & $\begin{array}{l}\text { Collaboration on the definition of the } \\
\text { work content } \\
\text { - Establishing and reinforcing the } \\
\text { framework of the collaboration } \\
\text { - Boosting the participants' motivation }\end{array}$ \\
\hline $\begin{array}{l}\text { Academic staff Unifr - Educational care } \\
\text { professionals - Staff from the Cité }\end{array}$ & $\begin{array}{l}\text { Phase 2: } \\
\text { Measurement } \\
\text { (pre-test) }\end{array}$ & Initial evaluations & $\begin{array}{l}\text { - Establishing the conditions for facilitating } \\
\text { measurement } \\
\text { - Consolidate collaboration }\end{array}$ \\
\hline $\begin{array}{l}\text { Academic staff Unifr - participants - Staff from } \\
\text { the Cité }\end{array}$ & $\begin{array}{l}\text { Phase 3: } \\
\text { Intervention }\end{array}$ & Training & $\begin{array}{l}\text { - Sharing expertise } \\
\text { - Designing tools and adjusting } \\
\text { implementation approach } \\
\text { - Consolidate collaboration }\end{array}$ \\
\hline $\begin{array}{l}\text { Academic staff Unifr - participants - Staff and } \\
\text { management from the Cité }\end{array}$ & $\begin{array}{l}\text { Phase 4: } \\
\text { Full session }\end{array}$ & & $\begin{array}{l}\text { - Sharing expertise } \\
\text { - Promoting collaboration } \\
\text { - Endorsement of tools and approach by the } \\
\text { entire system }\end{array}$ \\
\hline $\begin{array}{l}\text { Academic staff Unifr - Educational care } \\
\text { professionals - Cadres de la Cité }\end{array}$ & $\begin{array}{l}\text { Phase 5: } \\
\text { Measurement } \\
\text { (post-test) }\end{array}$ & Final evaluations & $\begin{array}{l}\text { - Establishing the conditions for facilitating } \\
\text { measurement } \\
\text { - Consolidate collaboration }\end{array}$ \\
\hline Academic staff Unifr & & Results processing & $\bullet$ \\
\hline Management and staff from the Cité & $\begin{array}{l}\text { Phase 6: } \\
\text { Continuing } \\
\text { implementation }\end{array}$ & $\begin{array}{l}\text { Inception of dialogue: } \\
\text { results/action on the } \\
\text { ground }\end{array}$ & $\begin{array}{l}\text { - Setting up the the It's my life working } \\
\text { group within the institution } \\
\text { - Adoption of the training approach by the } \\
\text { Cité's internal training organisation } \\
\text { - Engagement of a member of the research } \\
\text { team to continue with implementation at } \\
\text { the Cité }\end{array}$ \\
\hline Academic staff Unifr, Staff from the Cité & & $\begin{array}{l}\text { Circulation and } \\
\text { utilisation of the results }\end{array}$ & $\begin{array}{l}\text { - Publication of scientific articles } \\
\text { - Publication of a cartoon strip aimed at the } \\
\text { general public }\end{array}$ \\
\hline Academic staff Unifr & & & $\begin{array}{l}\text { - Publication of scientific articles } \\
\text { - Issue of a training manual } \\
\text { - Presentations to other social welfare } \\
\text { institutions and establishments } \\
\text { - Participation in scientific discussion } \\
\text { meetings }\end{array}$ \\
\hline $\begin{array}{l}\text { Academic staff Unifr, participants with an ID, } \\
\text { educational careprofessionals }\end{array}$ & & & $\begin{array}{l}\text { - Presentation of the knowledge acquired in } \\
\text { a university course }\end{array}$ \\
\hline
\end{tabular}


Submit or recommend next manuscript to SCIRP and we will provide best service for you:

Accepting pre-submission inquiries through Email, Facebook, LinkedIn, Twitter, etc. A wide selection of journals (inclusive of 9 subjects, more than 200 journals)

Providing 24-hour high-quality service

User-friendly online submission system

Fair and swift peer-review system

Efficient typesetting and proofreading procedure

Display of the result of downloads and visits, as well as the number of cited articles Maximum dissemination of your research work

Submit your manuscript at: http://papersubmission.scirp.org/

Or contact ce@scirp.org 